\title{
INCIDENCE OF THE ADJACENT SEGMENT DISEASE TREATED AT THE ISSEMYM MEDICAL CENTER
}

\author{
INCIDÊNCIA DA DOENÇA DO SEGMENTO ADJACENTE TRATADA NO \\ CENTRO MÉDICO ISSEMYM
}

\author{
INCIDENCIA DE LA ENFERMEDAD DEL SEGMENTO ADYACENTE TRATADA \\ EN EL CENTRO MÉDICO ISSEMYM
}

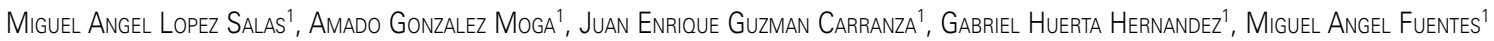

1. Centro Medico ISSEMYN, Ecatepec, Mexico.

\begin{abstract}
Objective: To determine the incidence and rate of disc degeneration adjacent to a lumbar fusion, as well as to analyze possible risk factors for its development. Methods: A retrospective study of a level of evidence IIB case series of 125 patients diagnosed with lumbar canal stenosis and spondylolisthesis, who underwent surgery from January 2011 to December 2016, with subsequent instrumentation and posterolateral fusion and outpatient follow-up in which the symptomatology and radiographic findings were evaluated to establish the diagnosis and management. Results: Twelve patients with adjacent segment disease were identified, with an incidence of $9.6 \%$, higher both among female patients and in the seventh decade of life. The most frequent pathology was canal stenosis (42.4\%), the most affected level was L4 / L5, and the procedure most associated with the prevalence of adjacent level degeneration was L4-L5 posterior transpedicular instrumentation. Conclusions: Sagittalization of the facet joint was a constant factor in all patients with involvement of the adjacent disc. The main clinical findings were treatment-resistant root pain and radiographic alterations characterized by spondylolisthesis, facet osteoarthritis and intervertebral disc herniation. Level of Evidence IIB; Retrospective study.
\end{abstract}

Keywords: Spinal disease; Lumbosacral region; Arthrodesis.

\section{RESUMO}

Objetivo: Determinar a incidência e a taxa de degeneração do disco adjacente, bem como analisar possíveis fatores de risco de degeneração do disco adjacente à fusão lombar. Métodos: Foi realizado um estudo retrospectivo de série de casos com nível de evidência IIB, com uma amostra de 125 pacientes com diagnóstico de estenose de canal lombar e espondilolistese, que foram operados no período de janeiro de 2011 a dezembro de 2016, com instrumentação posterior e fusão posterolateral e acompanhamento ambulatorial, no qual se avaliou a sintomatologia e os achados radiográficos para estabelecer o diagnóstico e o tratamento. Resultados: Foram identificados 12 pacientes com doença do segmento adjacente, com incidência de 9,6\%, com maior frequência no sexo feminino e na sétima década de vida. A patologia mais frequente foi estenose do canal (42,4\%). O nível mais afetado foi L4/L5, e o procedimento mais relacionado com a prevalência do nível adjacente foi a instrumentação transpedicular posterior em L4/L5. Conclusões: A sagitalização das facetas articulares tem sido um fator constante em todos os pacientes, com envolvimento do disco adjacente. Os principais achados clínicos são dor radicular resistente ao tratamento e alterações radiográficas caracterizadas por espondilolistese, artrose facetária e hérnia de disco intervertebral. Nível de Evidência IIB; Estudo retrospectivo.

Descritores: Doenças da coluna vertebral; Região lombossacral; Artrodese.

\section{RESUMEN}

Objetivo: Determinar la incidencia y tasa de degeneración del disco adyacente, así como analizar posibles factores de riesgo de desarrollar degeneración del disco adyacente a una fusión lumbar. Métodos: Se realizó un estudio retrospectivo de serie de casos con nivel de Evidencia IIB, con una muestra de 125 pacientes con diagnósticos de canal lumbar estrecho y espondilolistesis, intervenidos quirúrgicamente en el periodo de enero del 2011 a diciembre del 2016, con instrumentación posterior y fusión posterolateral, con seguimiento en consulta externa en el cual se evaluó la sintomatología y hallazgos radiográficos para establecer el diagnóstico y manejo. Resultados: Se identificaron 12 pacientes con enfermedad del segmento adyacente. Con una incidencia de 9,6\%, con mayor incidencia en el sexo femenino y mayor incidencia en la séptima década de la vida. La patología más frecuente ha sido la estenosis de canal (42,4\%). El nivel de mayor afectación fue en L4/L5, y el procedimiento más relacionado con la prevalencia de nivel adyacente fue la instrumentación posterior transpedicular L4/ L5. Conclusiones: La sagitalización de las facetas articulares ha sido un factor constante en todos los pacientes, con afectación del disco adyacente. Los principales hallazgos clínicos son dolor radicular resistente al tratamiento y alteraciones radiográficas caracterizadas por espondilolistesis, artrosis facetaria y hernia de disco intervertebral. Nivel de Evidencia IIB; Estudio retrospectivo.

Descriptores: Enfermedades de la Columna Vertebral; Región Lumbosacra; Artrodesis.

Study conducted at the Centro Medico ISSEMYN, Ecatepec, Mexico.

Correspondence: Centro Medico ISSEMYN Ecatepec, Ecatepe, Estado de Mexico, Avenida del Trabajo S/N, Col. El Carmen, CP 55000. dr.lopezsalas@ hotmail.com. 


\section{INTRODUCTION}

Hilibrand et al. classified adjacent segment involvement into two large groups: 1) subjects with "adjacent disc degeneration", which describes the radiographic changes seen in the adjacent disc as compared to the immediate results from the initial surgical procedure and which do not necessarily correspond to the clinical findings and 2) subjects with "adjacent segment disease", which refers to the development of new clinical symptoms that correspond to radiographic changes in the adjacent disc following previous vertebral fusion. ${ }^{1}$

Although the precise etiological mechanism for the development of adjacent disc involvement is unknown, degeneration of the mobile segments adjacent to a fusion has been described in the literature. In their biomechanical study using cadavers, Lee et al. observed a greater effort demand at the level of the disc adjacent to a lumbar fusion, with progressive degeneration and facet joint hypertrophy. ${ }^{2}$

Following posterior lumbar spine instrumentation, biomechanical changes characterized by increased loads associated with segment instability are presented. ${ }^{3}$ In order to diagnose adjacent segment disease, radiographical findings must be correlated with the presence of symptoms characterized by low back pain and radiculopathy, equal to the episodes prior to the procedure or new episodes occurring at least six months after the surgical procedure. ${ }^{4}$

In view of the studies conducted to date, it is reasonable to assume that both the progression of the degenerative disease and the biomechanical alterations seem to be determining factors in the development of adjacent disc disease. ${ }^{5}$

Risk factors include patient age (as the disease is more prevalent in people older than 55 years of age), sex, bone quality, type of procedure performed (laminectomy, facetectomy, or posterior transpedicular instrumentation), with a higher incidence in cases of degenerative spondylolisthesis, mainly at level L4-L5, and a higher incidence of presentation in the caudal levels of the lumbar spine. ${ }^{6}$

The main radiographic findings observed are disc degeneration, facet joint arthrosis, retro/anterolisthesis, instability ${ }^{7}$ (which is classified as a displacement of more than $4 \mathrm{~mm}$ in the anteroposterior plane, $10^{\circ}$ in the sagittal plane, more common in intervertebral disc herniation, and $5^{\circ}$ of rotation between the vertebral platforms), canal stenosis, intervertebral disc herniation, compression fractures, posterior osteophytes, and degenerative scoliosis. ${ }^{8}$

Treatment is based on revision surgery with posterior $360^{\circ}$ instrumentation ${ }^{9}$ (Posterior Lumbar Interbody Fusion, PLIF / Anterior Lumbar Interbody Fusion, ALIF, which have a lower incidence of adjacent segment involvement) with cephalad or caudad extension depending on the level affected. ${ }^{10,11}$

The objective of this retrospective study is to determine the incidence and rate of adjacent disc degeneration, as well as to analyze possible risk factors for the development of degeneration of the disc adjacent to a lumbar fusion.

\section{METHODS}

This is a retrospective study of a case series of 125 patients who underwent surgery with posterior instrumentation for degenerative lumbar pathology at the Centro Médico ISSEMYN Ectepec during the period from January 2011 to December 2016. The most frequent pathology was canal stenosis (42.4\%), followed by spondylolisthesis (32.8\%) and degeneration with disc herniation (24.8\%). Posterolateral arthrodesis instrumented with pedicle screws and heterologous graft plus bone matrix was performed in all patients, in addition to decompression in all those with neurological compromise. Followup of all patients was conducted in the outpatient clinic, where pain was clinically evaluated with the Visual Analog Scale (VAS), simple and dynamic radiographs were evaluated according to the stability criteria of White and Punjabi, and magnetic resonance images (MRI) were evaluated for disc degeneration, the presence of canal stenosis, and facet joint arthrosis. The fusion was considered to be correct if no interphase between the graft and the vertebral body was observed, there was an absence of instability in the dynamic radiographs, and there was good clinical tolerance.
Radiological criteria were used to define the involvement of the adjacent disc and the diagnosis was made via simple radiography and magnetic resonance. The adjacent disc was considered to be affected when a reduction in disc height greater than $4 \mathrm{~mm}$, anterior instability greater than $4 \mathrm{~mm}$, retrolisthesis and angulation greater than $10^{\circ}$ were observed in the simple radiograph, and when degenerative discopathy, disc protrusion or herniation, and segmental stenosis were observed in the MRI. The following risk factors were analyzed: age, sex, number of instrumented levels, the status of the limiting disc prior to surgery as assessed by MRI (MODIC scale), lordosis of the instrumented segment and the lumbosacral lordosis (Cobb angle), and the sagittalization of the facet joints of the limiting disc (MRI axial slices).

Twelve patients were diagnosed with adjacent segment disease during the previously mentioned period, who presented radiculopathy as well as reduced function mainly due to neurogenic claudication.

After establishing the adjacent segment disease diagnosis, surgical treatment based on the extension of the posterior instrumentation was proposed in $100 \%$ of the cases.

\section{RESULTS}

Twelve patients were identified with adjacent segment disease, (Figure 1) with an incidence of 9.6\%, an average presentation and surgical treatment period of 4.2 years, ranging from 1 to 7 years, a higher incidence in females (Figure 2), an average of 62 years of age, and higher incidence in the 7th decade of life. (Figure 3)

The most frequent pathology was canal stenosis (42.4\%), followed by spondylolisthesis (32.8\%) and degeneration with disc herniation (24.8\%). (Figure 4)

The most affected level was L4/L5 and the procedure most associated with the prevalence of adjacent level involvement was posterior L4/L5 transpedicular instrumentation. Posterior transpedicular instrumentation of L5/S1 was performed in 3 of the patients, in which the instrumentation was extended by one cephalad level. (Figure 5)

All of the patients diagnosed with adjacent segment disease were treated surgically with extensions of the instrumentation without any significant differences between the distal and proximal levels.

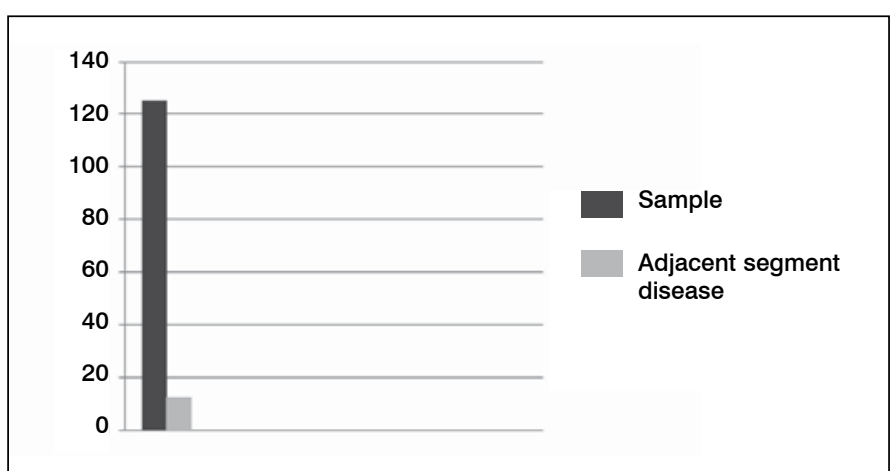

Figure 1. No. of patients diagnosed with adjacent segment disease.

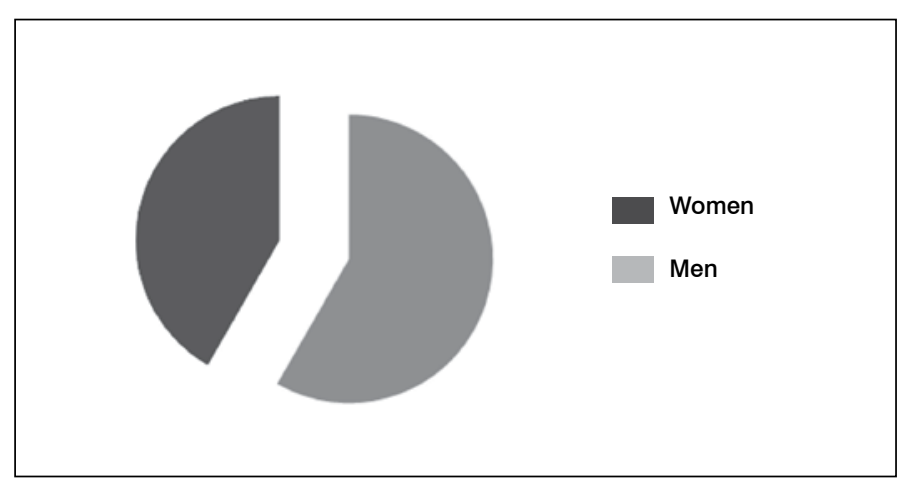

Figure 2. Incidence by sex. 


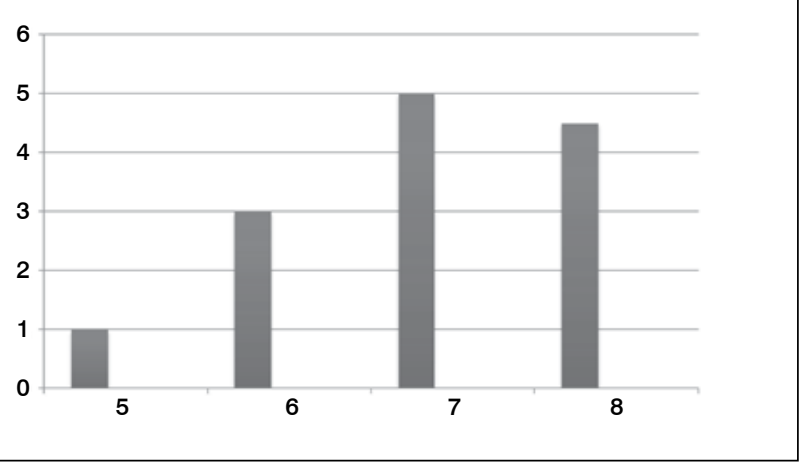

Figure 3. Age at presentation.

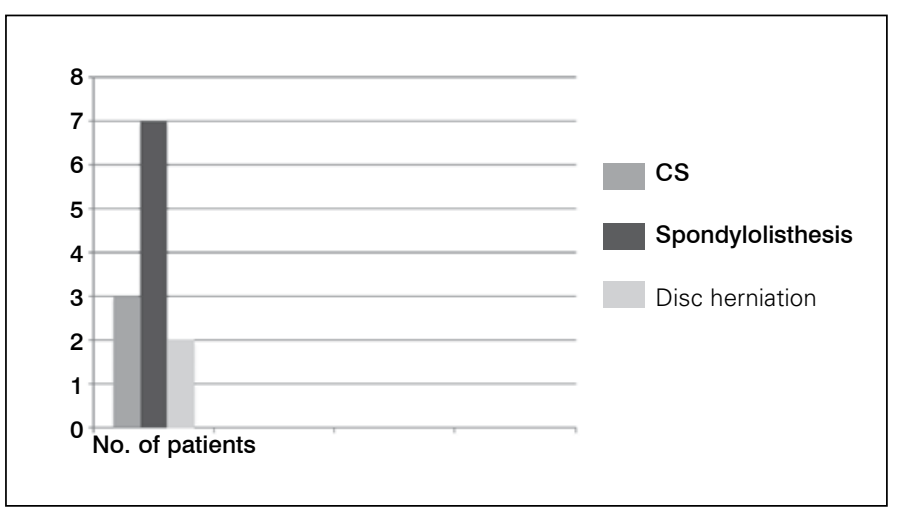

Figure 4. Total cases of degenerative pathology.

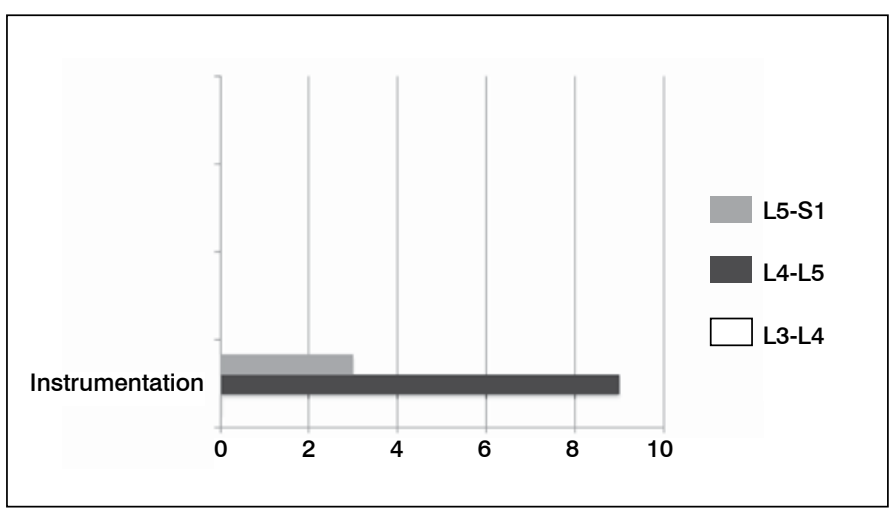

Figure 5. Instrumentation levels.

\section{DISCUSSION}

Degeneration of the disc adjacent to a lumbar fusion is a problem that is often described in the literature. Although the exact mechanism that produces this degeneration is uncertain, it seems that biomechanical changes can influence early involvement of the adjacent disc. There was a higher prevalence of adjacent segment disease among the women and an incidence of $9.6 \%$ during the period investigated, with higher incidence in the seventh decade of life and in patients with a history of canal stenosis (42.2\%). The average diagnosis and treatment time was 4.2 years, so it is important to identify degenerative pathologies of the adjacent level so they can be treated during the initial surgery in order to prevent progression to adjacent segment disease. Since our findings are correlated with the literature as regards L4/L5 being the principle level of involvement, the inclusion of the L5/S1 level in the first intervention may be a suitable alternative to prevent the progression of adjacent segment disease.

In the literature, injury to the inferior facet joint resulting from the placement of the pedicle instrumentation is described as a risk factor, as it can contribute to the instability of the limiting disc. Correct placement of the pedicle screws, without injury to the facet joint, may be a determining factor in reducing the incidence of adjacent disc injury. Changes in sagittal alignment are described in the literature as a possible risk factor for the development of disc involvement and are also implicated in adjacent disc involvement. The age and sex of patients are also indicated as risk factors in the literature, and in our study we observed greater affectation in women patients. The use of dynamic fixations or interspinous devices in the disc superior to an arthrodesis may well be an alternative in the prevention of this deterioration.

\section{CONCLUSIONS}

- More frequent in females.

- The main clinical findings are radicular pain resistant to treatment and with radiographic changes characterized by spondylolisthesis, facet joint arthrosis, and intervertebral disc herniation.

- The sagittalization of the facet joints was a constant factor in all the patients with adjacent disc involvement.

- The established treatment with the best evolution of clinical symptoms is extension of the instrumentation.

\section{ACKNOWLEDGEMENTS}

To the medical personnel, affiliates, and residents of the Spine Surgery service of the Hospital Centro Médico ISSEMYN ECATEPEC.

All authors declare no potential conflict of interest related to this article.

\section{REFERENCES}

1. Aota $Y$, Kumano K, Hirabayashi S. Postfusion instability at the adjacent segments after rigid pedicle screw fixation for degenerative lumbar spinal disorders. J Spinal Disord. 1995;8(6):464-73.

2. Guyer RD, Patterson M, Ohnmeiss DD. Failed back surgery syndrome: diagnostic evaluation. J Am Acad Orthop Surg. 2006;14(9):534-43.

3. Schlegel JD, Smith JA, Schleusener RL. Lumbar motion segment pathology adjacent to thoracolumbar, lumbar and lumbosacral fusions. Spine (Phila Pa 1976). 1996;21(8):970-81.

4. Lee CK, Langrana NA. Lumbosacral spinal fusion. A biomechanical study. Spine (Phila Pa 1976).1984;9(6):574-81.

5. Chou D, Dekutoski M, Hermsmeyer J, Norvell DC. The treatment of lumbar adjacent segment pathology after a previous lumbar surgery: a systematic review. Spine (Phila $\mathrm{Pa}$ 1976). 2012;37(Suppl 22):180-8.

6. Majid K, Fischgrund JS. Degenerative lumbar spondylolisthesis: trends in management. J Am Acad Orthop Surg. 2008;16(4):208-15.
7. Van Horn JR, Bohnen LM. The development of discopathy in lumbar discs adjacent to a lumbar anterior interbody spondylodesis. A retrospective matched-pair study with a postoperative follow-up of 16 years. Acta Orthop Belg. 1992;58(3):280-6.

8. Guigui P, Wodecki P, Bizot P, Lambert G, Chaumeil A. Deburge. Long-term influence of associated arthrodesis on adjacent segments in the treatment of lumbar stenosis: a series of 127 cases with 9-year follow-up. Rev Chir Orthop Repatrice Appar Mot. 2000;86(6):546-57.

9. Zencica P, Chaloupka R, Hladíková J, Krbec M. Adjacent segment degeneration after lumbosacral fusion in spondylolisthesis: a retrospective radiological and clinical analysis. Acta Chir Orthop Traumatol Cech. 2010;77(2):124-30.

10. Postigo RT, Lisoni AB. Enfermedades del segmento adyacente secundaria a intrumentación en cirugía de columna lumbar. Rev Méd Clín Condes. 2008;19(2):152-66.

11. Battié MC, Videman T, Parent E. Lumbar disc degeneration: epidemiology and genetics influences. Spine (Phila Pa 1976). 2004;29(23):2679-90. 